EXPERIMENTAL STUDY

\title{
PPAR $\gamma$ inhibits GH synthesis and secretion and increases apoptosis of pituitary GH-secreting adenomas
}

Fausto Bogazzi, Federica Ultimieri, Francesco Raggi, Dania Russo, Renato Vanacore ${ }^{1}$, Chiara Guida ${ }^{1}$, Paolo Viacava ${ }^{2}$, Denise Cecchetti ${ }^{2}$, Giovanni Acerbi ${ }^{3}$, Sandra Brogioni, Chiara Cosci, Maurizio Gasperi, Luigi Bartalena ${ }^{4}$ and Enio Martino

Department of Endocrinology and Metabolism, ${ }^{1}$ Transfusional Unit, ${ }^{2}$ Department of Oncology, ${ }^{3}$ Department of Neurosurgery, University of Pisa, 56124 , Pisa, Italy, ${ }^{4}$ Chair and Division of Endocrinology, University of Insubria, 21100, Varese, Italy

(Correspondence should be addressed to Fausto Bogazzi, Dipartimento di Endocrinologia e Metabolismo, Università di Pisa, Ospedale di Cisanello, Via Paradisa 2, 56124, Pisa, Italy; Email: f.bogazzi@endoc.med.unipi.it or fbogazzi@hotmail.com)

\begin{abstract}
Objective: The objective of the study was to evaluate the expression and functional activity of Peroxisome proliferator-activated receptor (PPAR) $\gamma$ in pituitary adenomas from 14 consecutive acromegalic patients and to establish its role in apoptosis.

Subjects and methods: Fourteen consecutive acromegalic patients were enrolled in the study. Wistar-Furth rats were used for in vivo studies. Expression of PPAR $\gamma$ was evaluated by RT-PCR and Western blot. Apoptosis and cell cycle were assessed by FACS analysis. The effects of PPAR $y$ ligands on transcriptional regulation of GH gene were evaluated by RT-PCR and electromobility shift assay. Results: PPAR $\gamma$ was expressed in all human GH-secreting adenoma (GH-oma), in normal pituitary tissue samples $(39 \pm 24 \%$ and $78 \pm 5 \%$ of immunostained nuclei respectively; $P<0.0002$; ANOVA), and in rat GH-secreting (GH3) cells. A PPRE-containing reporter plasmid transfected into GH3 cells was activated by ciglitazone or rosiglitazone (TZDs), indicating that PPAR $\gamma$ was functionally active. Treatment of GH3 cells with TZDs increased apoptosis in a dose-dependent manner $(P=0.0003)$ and arrested cell proliferation, reducing the number of cells in the S-phase $(P<0.0001$ vs untreated cells). TZDs increased the expression of TRAIL, leaving unaffected that of p53 and Bax. TZDs reduced GH concentrations in the culture media from $43.7 \pm 5.4 \mathrm{ng} / \mathrm{ml}$ to $2.1 \pm 0.3 \mathrm{ng} / \mathrm{ml}(P<0.0001)$ and in cell extracts $(P<0.004)$. PPAR $\gamma-\mathrm{RXR} \alpha$ heterodimers bound to $\mathrm{GH}$ promoter, inhibiting its activity and reducing GH mRNA levels $\left(1.8 \times 10^{6}\right.$ vs $5.7 \times 10^{6}$ transcripts respectively vs untreated cells; $P<0.002)$. Subcutaneous GH-oma developed in rats injected with GH3 cells; tumor growth increased in placebo-treated rats and to a lesser extent in TZDs-treated animals $(24.1 \pm 2.0 \mathrm{~g}$, and $14.8 \pm 4.2 \mathrm{~g}$ respectively, $P<0.03)$. Serum GH concentrations were lower in TZDs-treated rats than in controls $(871 \pm 67 \mathrm{ng} / \mathrm{ml}$ vs $1.309 \pm 238 \mathrm{ng} / \mathrm{ml} ; P<0.05)$.

Conclusions: The results of this study indicate that PPAR $\gamma$ controls GH transcription and secretion as well as apoptosis and growth of GH-oma; thus, TZDs have the potential of a useful tool in the complex therapeutic management of acromegalic patients.
\end{abstract}

European Journal of Endocrinology 150 863-875

\section{Introduction}

Acromegaly is a syndrome characterized by excessive growth hormone $(\mathrm{GH})$ secretion from pituitary adenomas, which in turns leads to overexpression of insulin-like growth factor (IGF)-I, the main effector of $\mathrm{GH}$ action $(1,2)$. The treatment of acromegaly is a therapeutic challenge (3). In spite of combination of surgery, external X-ray therapy and medical therapy, many patients continue to have uncontrolled $\mathrm{GH}$ secretion and active disease $(4-15)$.

Peroxisome proliferator-activated receptor (PPAR) $\gamma$ is a ligand-dependent transcription factor belonging to the nuclear receptor superfamily (16); it is highly expressed in adipose tissue, where it plays a key role in the regulation of adipocyte differentiation and fat metabolism $(17,18)$, and in colonic mucosa, where it exerts important functions in the differentiation process (19, 20). It is a functional receptor for the thiazolidinedione (TZDs) class of antidiabetic drugs and may function as a tumor-suppressor gene $(21,22)$; its activation has been reported to induce differentiation of liposarcoma (23), prostate cancer (24) or several transformed cells $(19,25)$.

PPAR $\gamma$ activation induced apoptosis in human and rat glioma with a transient upregulation of Bax and 
Bad proteins levels (26); in human papillary thyroid carcinoma cells, in which it enhanced expression of c-myc (27); and in the colonic cancer HT-29 cell line, where it downregulated c-myc and upregulated c-jun and gadd153 (28).

Recently, Heaney et al. $(29,30)$ reported that expression of PPAR $\gamma$ in normal pituitary gland seemed to be restricted to ACTH-secreting cells; nevertheless, this receptor was expressed in almost all pituitary adenomas.

However, PPAR $y$ expression was studied in only three pure pituitary GH-secreting tumors (30). Activation of PPAR $\gamma$ induced apoptosis in various pituitary tumor cell lines $(29,30)$ and reduced the levels of ACTH, prolactin (PRL) and GH in the culture media. Nude mice injected with the pituitary GH-secreting GH3 cells harbored subcutaneous tumors, the development of which was partially prevented or retarded by the simultaneous treatment with TZDs (30). The increased TZDs-dependent apoptosis of rat pituitary cell lines was associated with the reduced expression of the antiapoptotic protein $\mathrm{Bcl} 2$ and increased levels of proapoptotic Bax or p53 expression (29). However, spontaneous GH-secreting adenomas developed before a chemopreventive treatment could be initiated. In other words, therapies can be started only after acromegaly has become clinically manifest. Thus, it is more appropriate to evaluate the effects of TZDs on a pituitary tumor after its development.

TZDs treatment reduced cell viability and reduced the expression of pro-opiomelanocortin mRNA of ACTHsecreting cells. However, it is not known whether reduction of $\mathrm{GH}$ levels in the culture media of $\mathrm{GH} 3$ cells or in whole animals carrying subcutaneous GHomas was due to the antiapoptotic effects of TZDs or to decreased transcription of the $\mathrm{GH}$ gene.

Taking into account the reported expression of PPAR $\gamma$ in the pituitary and the antiproliferative effects of PPAR $\gamma$ ligands, we performed a series of experiments to evaluate the effect of this nuclear receptor on cell viability and $\mathrm{GH}$ secretion of pituitary GH-secreting adenomas. The aim of the study was to examine the expression of PPAR $\gamma$ in the pituitary adenoma from 14 consecutive patients with acromegaly and in normal pituitary tissue samples, to determine the effects of PPAR $\gamma$ activation in promoting apoptosis, and reducing tumor growth and $\mathrm{GH}$ secretion of adenoma either in vitro or in vivo, and to study the PPAR $\gamma$-dependent transcriptional regulation of human $\mathrm{GH}$ gene.

\section{Materials and methods}

\section{Pituitary GH-secreting adenoma and normal pituitary tissue}

Pituitary GH-secreting adenomas samples were obtained from 14 consecutive acromegalic patients submitted to trans-sphenoidal adenomectomy. All acromegalic patients included in the present study had a pure $\mathrm{GH}-$ secreting adenoma and received a 6-month trial with somatostatin analogs before surgery. Normal pituitary tissue samples comprised the tissue outside pituitary adenomas obtained during neurosurgical excision of nine pituitary adenomas (five $\mathrm{GH}$-secreting adenomas of the present series and four nonfunctioning adenomas). Pituitary tissue surrounding pituitary adenomas was considered normal at gross analysis by the neurosurgeon and the pathologist; in addition, all pituitary tissue samples surrounding pituitary adenomas were positively immunostained with anti-ACTH, anti-TSH (thyroid-stimulating hormone), anti-PRL, anti-LH and anti-FSH (follicle-stimulating hormone) antibody (data not shown). Samples of normal adult human skin $(n=5)$ were obtained during plastic surgery. All patients gave their informed consent, and the study was approved by the institutional review committee. Tissue samples were either immediately stored in liquid nitrogen for subsequent analysis or embedded in paraffin. Sections of pituitary tissue samples were immunostained with an anti-human GH antibody or an anti-PPAR $\gamma$ antibody, as previously described (31). Negative controls were obtained by omitting the anti-PPAR $\gamma$ - or anti-GH-specific primary antibodies, which were replaced by rabbit nonimmune serum.

\section{Cell culture and cell preparation}

GH3 and NIH3T3 cell lines were obtained from Data Bank ISDT (Genua, Italy) and cultured in F10 (GH3) or DMEM (NIH3T3), 10\% FCS, 2 mM glutamine and penicillin-streptomycin solution, in a humidified 5\% $\mathrm{CO}_{2}$ atmosphere at $37^{\circ} \mathrm{C}$. Under starvation conditions, cells were extensively washed in PBS, and then incubated for $12 \mathrm{~h}$ in serum-free medium.

The effect of PPAR $\gamma$ activation on apoptosis and cell cycle was evaluated either in starved cells or in cells cultured in complete medium in the absence or presence of $1-50 \mu \mathrm{M}$ ciglitazone (cig) (Alexis Biochemicals, San Diego, CA, USA) or $1-50 \mu \mathrm{M}$ rosiglitazone (ros) (kindly provided by Glaxo-Kline-Beecham, Milan, Italy). Assessment of apoptosis by Annexin V or DNA fragmentation assay was done after up to $72 \mathrm{~h}$ of culture (see below).

\section{Annexin $V$ binding assay}

Cells were washed in PBS, trypsinized, centrifuged and washed with PBS before incubating with FITC-labeled monoclonal annexin $\mathrm{V}$ antibody and propidium iodide for $15 \mathrm{~min}$ at RT according to the supplier's instructions (Sigma-Aldrich, Milan, Italy) with few modifications. Cells were analyzed on a FACS (FACS Calibur) Becton Dickinson (Franklin Lakes, NJ, USA) apparatus. For each sample, 500000 cells were analyzed. Data were analyzed using Cell Quest software (Becton Dickinson, Franklin Lakes, NJ, USA) and 
represent the mean \pm S.D. of five different experiments, each performed in triplicate.

\section{DNA fragmentation assay}

Quantitative determination of fragmentated DNA in cytoplasm was done by Cell Death Detection ELISA Plus (Roche Diagnostics, Indianapolis, IN, USA), which detects the amount of histone-associated DNA fragments. The assay was performed according to the supplier's manual; briefly, $10^{4}$ cells were grown in a 96-well culture plate for $24 \mathrm{~h}$, either starved for $12 \mathrm{~h}$ or maintained in complete medium for an additional $12 \mathrm{~h}$, and then incubated with either ros or cig for up $72 \mathrm{~h}$, as indicated in the cell culture and cell preparation section. Supernatant culture media were removed, lysis buffer was added to each vial and histone-associated DNA fragments were colorimetrically quantified. Data represent the mean \pm S.D. of five independent experiments, each performed in triplicate.

\section{Cell-cycle analysis}

GH3 or NIH3T3 cells either starved or cultured in complete grown medium were treated with either $1-50 \mu \mathrm{M}$ ros or cig, or were untreated for $24 \mathrm{~h}$; cells were trypsinized, collected by centrifugation washed with PBS and treated with RNase A (Promega, Madison, WI, USA). DNA was stained with propidium iodide for $15 \mathrm{~min}$ at $4^{\circ} \mathrm{C}$ and analyzed with a FACS Calibur (Becton Dickinson, Franklin Lakes, NJ, USA) apparatus. Analysis was by ModFit LT software (Becton Dickinson, Franklin Lakes, NJ, USA). Experiments were carried out in triplicate and repeated three times.

\section{Antibodies}

Human polyclonal anti-p53, anti-TRAIL, anti-Bax, anti-PPAR $\gamma$ and anti- $\beta$-actin antibody were obtained from Santa Cruz Biotechnology (Santa Cruz, CA, USA).

\section{Immunoblotting}

Cells $\left(9 \times 10^{6}\right)$ were washed in PBS and lysed in lysis buffer (50 mM TRIS-HCl, pH 6.8, 10\% glycerol, 2.5\% SDS, $10 \mathrm{mM}$ DTT and $1 \mathrm{mM}$ PMSF). Nuclear extracts were prepared as previously reported (32). Protein concentration was measured by Bradford assay using the Bio-Rad reagent (Bio-Rad Laboratories, Hercules, CA, USA). Proteins $(25 \mu \mathrm{g})$ were resolved by $12 \%$ SDSPAGE, transferred onto nitrocellulose membrane and stained with red ponceau to verify the amount of protein per lane. Nuclear extracts or whole-cell extracts were incubated overnight at $4{ }^{\circ} \mathrm{C}$ in $50 \%$ TBS (200 mM TRIS-HCl, pH 7.6, and $1.4 \mathrm{M} \mathrm{NaCl}$ ) and 50\% TTBS (TBS, $0.05 \%$ Tween-20), containing 5\% nonfat dry milk, and subsequently incubated with the appropriate primary antibody for $1 \mathrm{~h}$ at RT. After extensive washing in TTBS, a horseradish peroxidase-conjugated antirabbit IgG was added for $1 \mathrm{~h}$. After four washings of the membranes with TTBS and TBS, proteins were detected using an enhanced chemiluminescence detection system (Amersham Pharmacia Biotech, Piscataway NJ, USA). Experiments were performed three times with different nuclear or cell extracts.

\section{Transfections and plasmids}

The pBLCAT $2_{\text {PPRE }}$ vector containing a single copy of the PPAR response element of the acylCoA-oxidase gene has been described (33). Some $2 \times 10^{5}$ GH3 cells were transiently transfected with $10 \mu \mathrm{g}$ of the pBLCAT $2_{\text {PPRE }}$ plasmid or the empty parental vector and $1 \mu \mathrm{g}$ of the $\mathrm{PCH} 110$ plasmid containing the $\beta$ galactosidase gene, using the calcium phosphate method; the latter plasmid was used to account for the variation of transfection efficiency. NIH3T3 cells were transiently transfected under the same conditions or cotransfected with pBLCAT2 $2_{\text {PPRE }}$ and pSG5-PPAR $\gamma$ plasmid. Cell extracts were prepared $48 \mathrm{~h}$ later, and chloramphenycol acetyl transferase (CAT) assay and $\beta$-gal assay were performed as previously described (33). Results were expressed as arbitrary units considering $100 \%$ of the value obtained in the absence of cig or ros. Cig or ros were used at $1-10 \mu \mathrm{M}$. GH3 cells were transfected with the pBLCAT3-hGH plasmid containing the $-397 /+1$ DNA sequence of the $5^{\prime}$-flanking region of the hGH gene, which was obtained by amplifying the corresponding sequence from the phGH plasmid (a gift of Dr N. Eberhardt, Mayo Clinic, USA). The integrity of the DNA fragment was confirmed by sequencing analysis. Data represent the mean of four independent experiments performed in triplicate.

\section{Gel mobility shift assay}

Expression vectors pSG5-PPAR $\gamma$ and pSG5-RXR $\alpha$ containing the cDNA of human PPAR $\gamma$ (kindly provided by Dr B. Desvergne, Lausanne, Switzerland) or mouse RXR $\alpha$ (kindly provided by Dr R.M. Evans, San Diego, CA, USA) were used for in vitro transcription-translation by the reticulocyte lysate system. The unprogrammed reticulocyte lysate was used as a negative control. The $-397 /-144,-397 /+1$ and $-144 /+1$ fragments of the hGH promoter were obtained by PCR amplification of the original phGH plasmid, purified and ${ }^{32}$ P-labeled with T4 polynucleotide kinase. The binding reaction was carried out as previously reported (33); the DNA-protein complexes were resolved on a $5 \%$ nondenaturing polyacrylamide gel at $4{ }^{\circ} \mathrm{C}$; gels were dried and exposed to autoradiography at $-70^{\circ} \mathrm{C}$.

\section{RT-PCR for GH}

An amount of $1 \mu \mathrm{g}$ of total RNA obtained from $30 \times 10^{6} \mathrm{GH} 3$ or NIH3T3 cells was reverse-transcribed 

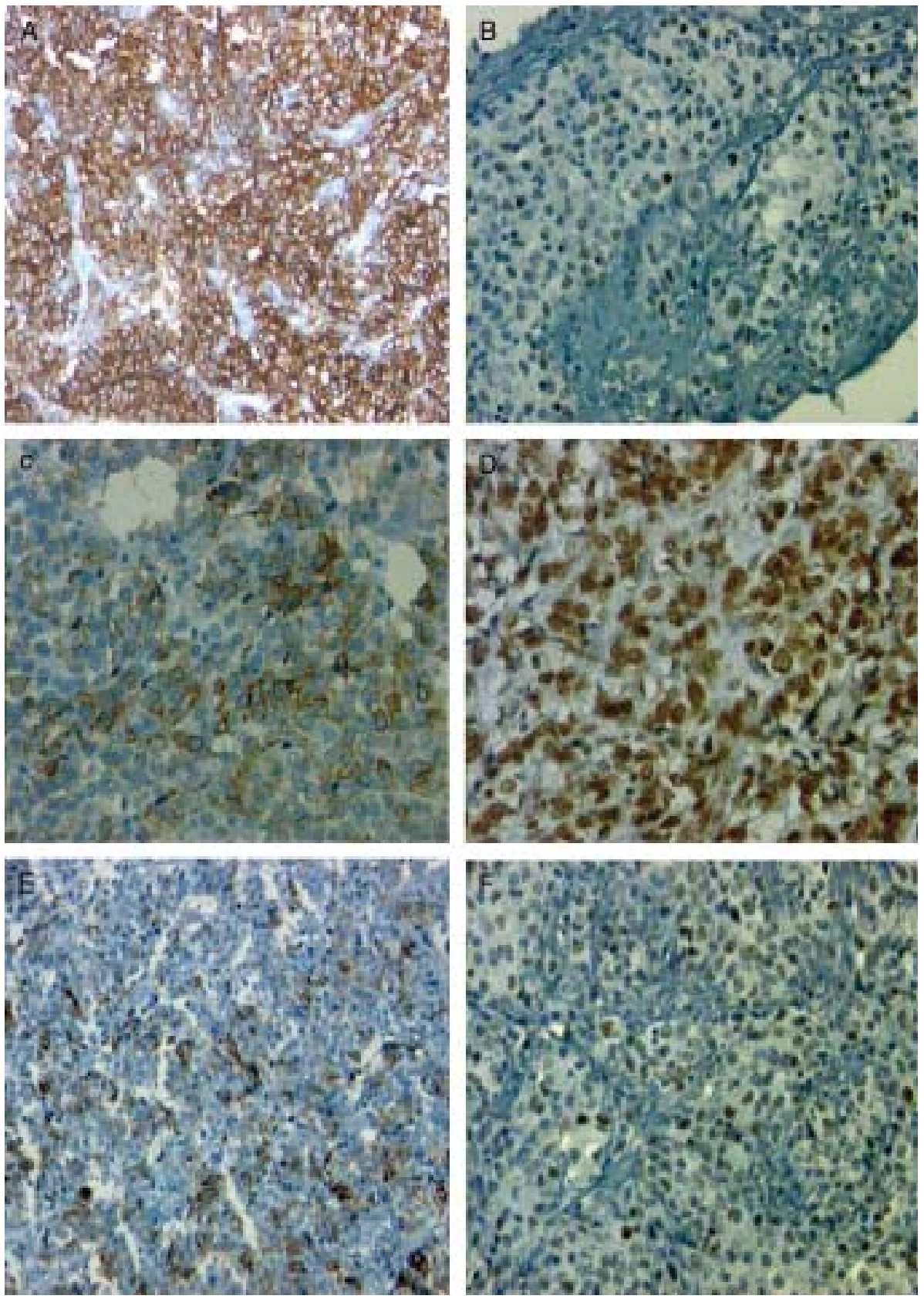

Figure 1 Expression of PPAR $\gamma$ in human pituitary GH-secreting tumors, in normal pituitary tissue and in GH3 cells. Panel 1) Tissue samples were obtained from 14 consecutive acromegalic patients with pure $\mathrm{GH}$-secreting adenoma undergoing surgical excision of the tumor. Normal pituitary tissue samples were obtained during tumor excision of five GH-secreting adenomas (from the present series) and four nonfunctioning adenomas (panel $1 \mathrm{H}$ ). Immunohistochemistry was performed using a specific antibody against human GH (panel $1 \mathrm{~A}$ and $\mathrm{C}$ (GH-omas), and $\mathrm{E}$ (normal tissue)) or the $\mathrm{N}$-terminus of PPAR $($ panel 1B and D (GH-omas), and $\mathrm{F}$ (normal tissue)). Negative control was a GH-secreting tumor incubated with nonimmune serum (not shown). Original magnification $\times 250$. Mean PPARy expression, evaluated as percentage of stained nuclei, was $39 \pm 24$ in $\mathrm{GH}$-secreting adenomas and $78 \pm 5$ in normal tissue $(P<0.0002)$; representative colocalization of PPAR $\gamma$ and GH in normal pituitary tissue (panel 1G). Panel 2) Representative Western blot of three human pituitary GH-secreting adenomas (ACRO 5, 4 and 9) and three normal pituitary tissue samples (N Pit 5, 4 and 9). Nuclear extracts from human tissue samples, rat GH3 and mouse NIH3T3 cells were immunoblotted with a specific antibody against PPAR In vitro synthesized PPAR $y$ was used as a positive control; nuclear extracts from human skin and from NIH3T3 cells were used as a negative control. Panel 3) GH3 cells were transiently transfected with the pBLCAT2PPRE vector containing the PPAR response element of the acylCoA-oxidase gene and exposed to $1 \mu \mathrm{M}$ ciglitazone (cig) or rosiglitazone (ros). NIH3T3 cells were transfected with the same reporter gene alone or cotransfected with pBLCAT2 PPRE plasmid and PSG5-PPAR $\gamma$. Data were expressed as relative CAT activity, assuming that the CAT activity obtained with the vehicle was considered $100 \%$. Results represent the mean of four experiments carried out in triplicate. 


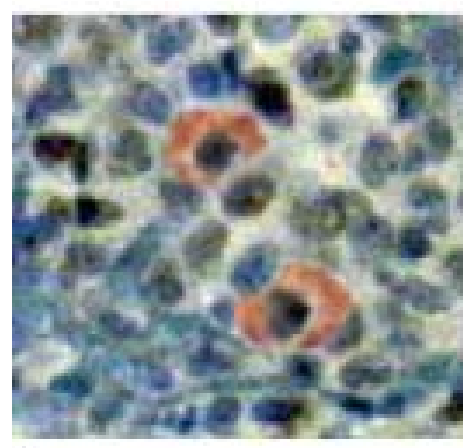

G

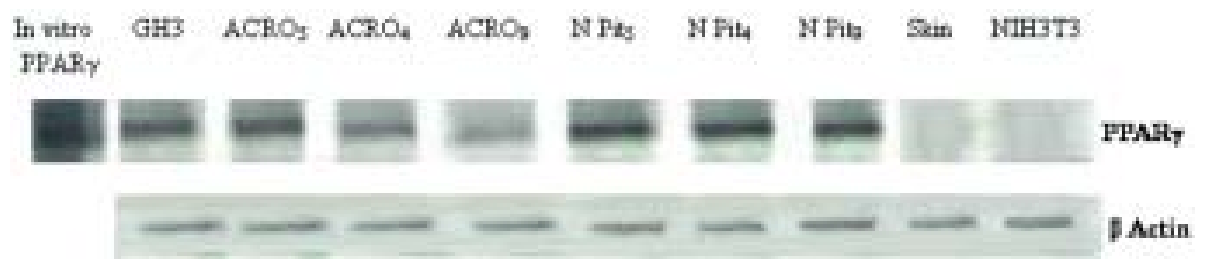

Figure 1 Continued.

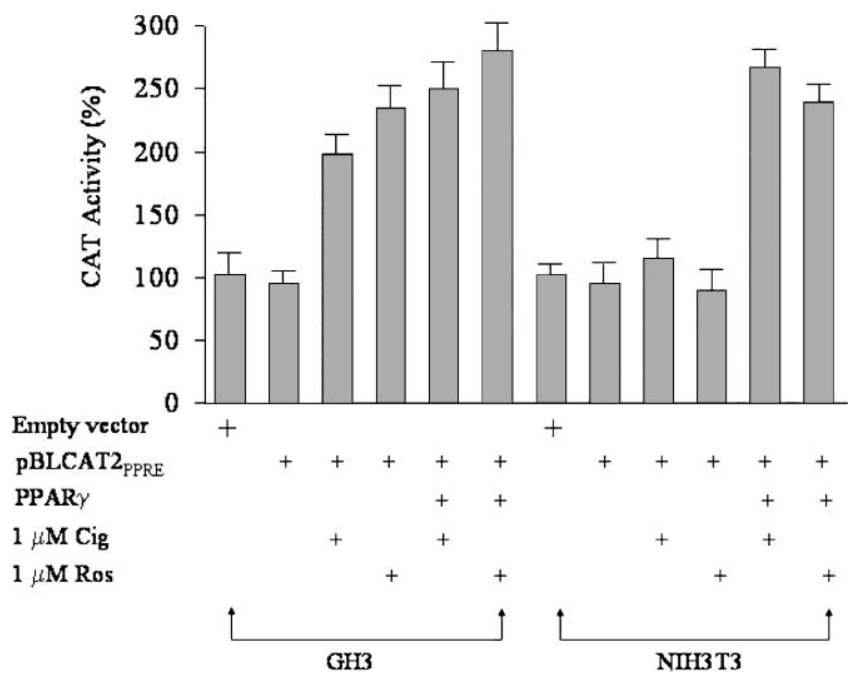

in $50 \mathrm{mM}$ Tris $\mathrm{HCl}(\mathrm{pH} 8.3), 75 \mathrm{mM} \mathrm{KCl}, 3 \mathrm{mM} \mathrm{MgCl} 2$, $10 \mathrm{mM}$ DTT, $200 \mu \mathrm{M}$ each dNTP, $10 \mathrm{mM}$ Oligo (dT) primer, 20 U Rnasin (Promega) and 200 U M-MLV RT, in a final volume of $20 \mu \mathrm{l}$. The reaction was terminated by heating at $95^{\circ} \mathrm{C}$ for $5 \mathrm{~min}$. A volume of $5 \mu \mathrm{l}$ of the reaction was then amplified in a final volume of $25 \mu \mathrm{l}$ in $1 \times$ PCR buffer (Taq Man Universal PCR Master Mix, supplied by Applied Biosystems (Foster City, CA, USA), $300 \mathrm{mM}$ of each primer and $200 \mathrm{nM}$ of fluoresceinate probe for 34 cycles, as 
previously reported (34). Primers and the probe were as follows: primer sense, 5'-gctggctgctgacacctaca-3'; primer antisense, 5'-cctgggcattctgaatggaa-3'; and probe, 5'-6FAM-agttcgagcgtgcctacattcccga-TAMRA-3'. The primers set amplify a $80 \mathrm{bp}$ fragment, the identity of which was confirmed by DNA sequencing. A control in which reverse transcription was omitted before PCR amplification was always included to exclude the possibility that any amplification was due to contaminating genomic DNA. Each experiment was performed in triplicate; data are expressed as number of copies of $\mathrm{GH}$ and represent the mean of three independent experiments.

\section{GH assays}

Cell-culture media were collected after exposure of cells to $1,10,50 \mu \mathrm{M}$ cig or ros; cell lysates were obtained by treating the cells with lysis buffer $(50 \mathrm{mM}$ TRIS-HCl, $\mathrm{pH}$ 6.8, 10\% glycerol, 2.5\% SDS and $10 \mathrm{mM}$ DTT); after centrifugation, supernatants were sonicated; blood samples were obtained from animals at baseline (before GH3 cells injection) and when rats were killed. $\mathrm{GH}$ was determined by radioimmunoassay (Amersham Biosciences). Measurement of GH in the cell lysates was normalized by protein concentrations. Sensitivity of GH assay was $1.0 \mathrm{ng} / \mathrm{ml}$.

\begin{abstract}
Animals
Five-week-old female Wistar-Furth rats were obtained from Harlan (Udine, Italy) and inoculated with $2 \times 10^{6}$ rat pituitary GH-secreting tumor cells, in accordance with the animal care committee of our institution; after subcutaneous tumor development, animals were randomized to receive ros $(120 \mathrm{mg} / \mathrm{kg}$ per day) or vehicle. The dose of the drug was based on preliminary results with $40 \mathrm{mg} / \mathrm{kg}$ per day, which was ineffective. Ros was administered daily by gavage. Rats were killed by chloralium hydrate, and the tumors were weighed, and stored in liquid nitrogen.
\end{abstract}

\section{Statistics}

Data were expressed as mean \pm S.D. Comparison of parameters was performed by the analysis of variance (ANOVA).

\section{Results}

\section{PPAR $\gamma$ expression in pituitary GH-secreting tumors and normal pituitary tissues}

The expression of PPAR $\gamma$ was assessed in 14 consecutive surgically resected pituitary GH-secreting adenomas (GH-oma) and in nine normal pituitary tissue samples. Expression of PPAR $\gamma$ was analyzed by immunohistochemistry. PPAR $\gamma$ protein was intensively expressed, albeit showing heterogeneous distribution, in all pituitary GH-omas (Fig. 1, panel 1). Immunostained nuclei ranged $5-80 \%$ (mean $39 \pm 24 \%$ ) in GH-omas, and $70-85 \%$ (mean $78 \pm 5 \%$ ) in normal pituitary tissue samples $(P<0.0002)$. PPAR $\gamma$ and GH colocalized in the same pituitary cells as shown by double immunostaining (Fig. 1, panel 1). The presence of PPAR $\gamma$ was confirmed in nuclear extracts from pituitary normal tissue, GH-oma and GH3 cell extracts by Western blot; in vitro synthesized PPAR $\gamma$ was used as a positive control, while extracts of normal adult human skin and extracts of NIH3T3 cells were used as a negative control (35) (Fig. 1, panel 2). To evaluate the functional integrity of the receptor in GH3 cells, a reporter plasmid containing a PPRE fused to a heterologous promoter and a reporter gene (pBLCAT $2_{\text {PPRE }}$ ), was transiently transfected into either GH3 or NIH3T3 cells. Addition of $1 \mu \mathrm{M}$ cig or ros increased the basal level of expression of the reporter plasmid by 1.8 -fold and 2.2-fold respectively only in GH3 cells, indicating that this cell line expressed a functionally integer PPAR $\gamma$ (Fig. 1, panel 3). Cotransfection of PPAR $\gamma$ was necessary to activate the pBLCAT $2_{\text {PPRE }}$ plasmid in NIH3T3 cells, indicating the absence of a significant amount of functionally active PPAR $\gamma$ in this cell line.

\section{PPAR $\gamma$ ligands increase apoptosis in GH3 cells}

$\mathrm{GH} 3$ cells exposed to either $1-50 \mu \mathrm{M}$ cig or ros for up to $72 \mathrm{~h}$ exhibited an increased apoptosis rate (Fig. 2). Apoptosis increased from $17.0 \pm 2.3 \%$ to $36.0 \pm 6.5 \%$ $(P<0.004)$ and to $44.3 \pm 6.0 \%(P=0.0007)$ in cells cultured in complete medium after exposure to $50 \mu \mathrm{M}$ cig or $50 \mu \mathrm{M}$ ros respectively, as assessed by the annexin $\mathrm{V}$ iodide propidium method (Fig. 2 panel 1); treatment of starved cells with either $1-50 \mu \mathrm{M}$ cig or ros gave similar results (data not shown). Treatment of NIH3T3 cells with either cig or ros did not affect the apoptosis rate, thus indicating the specificity of action of PPAR $\gamma$ agonists (Fig. 2, panel 2). Apoptosis increased in a dose-dependent manner in GH3 cells treated with either cig or ros up to 2.5-fold, as assessed by measuring the amount of histone-associated DNA fragments $(P=0.0003)$ (Fig. 2, panel 3).

\section{Effects of PPAR $\gamma$ ligands on GH3 proliferation}

Treatment with $1-50 \mu \mathrm{M}$ cig or ros for up $72 \mathrm{~h}$ increased the number of $\mathrm{GH} 3$ cells in the G1 phase $(92 \pm 4 \%$ vs $73 \pm 3 \%$ in controls, $P<0.001)$ and reduced the cells in the $S$-phase $(8.5 \pm 0.9$ vs $18.5 \pm 0.5 \%$ in controls, $P<0.0001)$ of cells grown in complete medium, thus indicating a GO-G1 cell-cycle arrest (Fig. 3). Similar results were obtained in starved GH3 cells (data not shown). Treatment with either cig or ros did not affect the cell cycle of NIH3T3 cells (Fig. 3). 


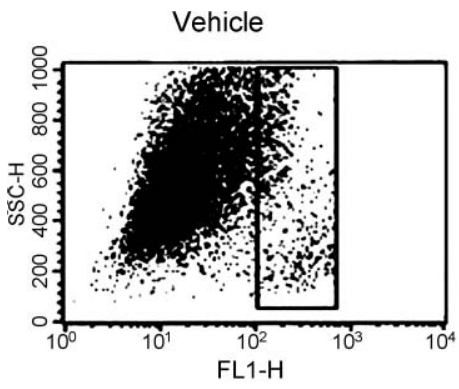

$17.0 \pm 2.3$

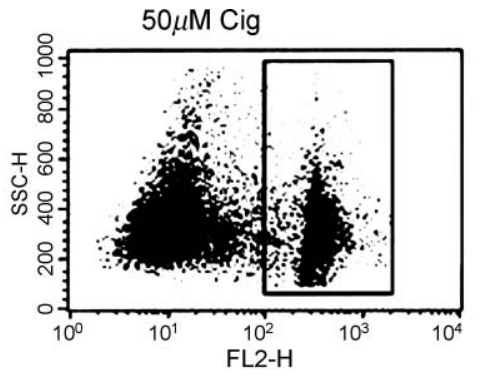

$36.0 \pm 6.5$

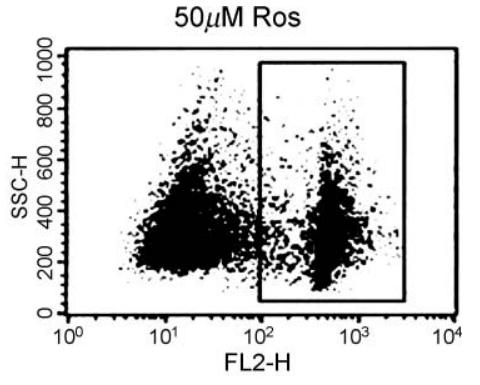

$44.3 \pm 6.0$

$\mathrm{GH} 3$ cells, Apoptosis \% (mean $\pm \mathrm{SD})$

$50 \mu \mathrm{M} \mathrm{Cig}$

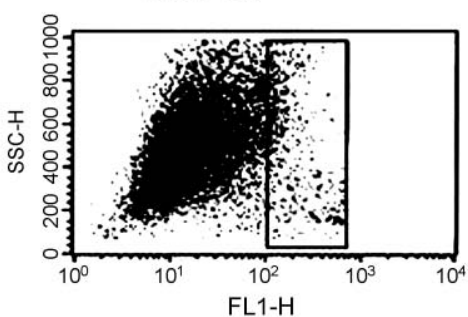

$6.5 \pm 0.3$
$50 \mu \mathrm{M}$ Ros

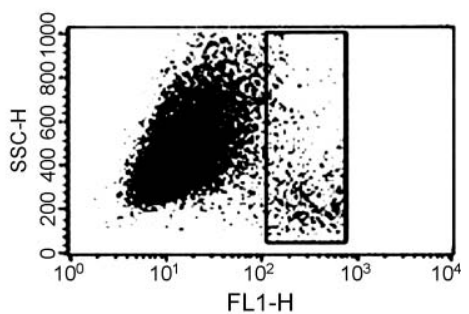

$6.9 \pm 1.7$

NIH3T3 cells, Apoptosis \% (mean \pm SD)

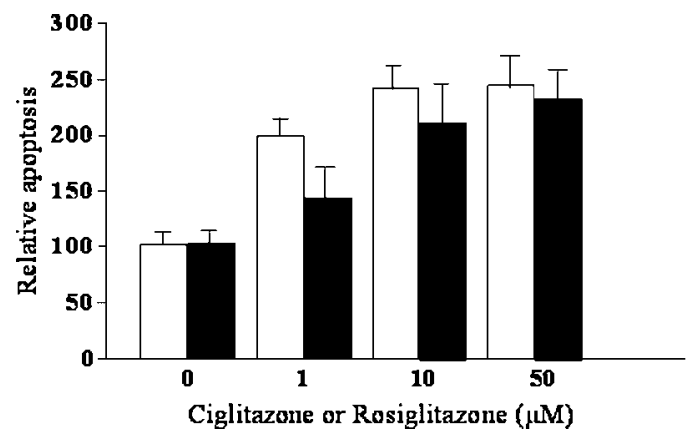

Figure 2 Induction of apoptosis by PPAR $\gamma$ ligands in GH3 and NIH3T3 cells. Cells were either starved for $12 \mathrm{~h}$ or cultured in complete medium and then exposed to $1-50 \mu \mathrm{M}$ cig or ros for up to $72 \mathrm{~h}$. Panel 1 shows the rate of apoptosis evaluated by the annexin V-propidium iodide method. Apoptotic cells (within the box) increased from $17.0 \pm 2.3 \%$ to $36.0 \pm 6.5 \%(P<0.004)$ and to $44.3 \pm 6.0$

$(P=0.0007)$ in $\mathrm{GH} 3$ grown in complete medium and treated with either $50 \mu \mathrm{M}$ cig or ros, respectively. Panel 2 shows that cig or ros did not increase the apoptosis rate of NIH3T3 cells. Panel 3 shows the dose-dependent induction of apoptosis of cig- or ros-treated GH3 cells evaluated by measuring the amount of fragmentated DNA by the cell death kit, as reported in Materials and methods $(P=0.0003)$; cells were exposed to $1-50 \mu \mathrm{M}$ TZDs. Results are expressed as relative apoptosis considering the value observed in untreated cells as $100 \%$. Results are expressed as mean \pm S.D. of five different experiments, each performed in triplicate.

\section{Effects of PPAR $\gamma$ ligands on apoptosis- associated proteins}

GH3 cells were treated with either $50 \mu \mathrm{M}$ cig or ros for up $72 \mathrm{~h}$. Cellular extracts were immunoblotted with specific antibody against p53, TRAIL and Bax. Expression of p53 and Bax was not affected by either cig or ros treatment, while activation of PPAR $\gamma$ by these drugs was associated with increased expression of TRAIL proteins (Fig. 4). NIH3T3 cell extracts were not used because the apoptosis rate of this cell line was not affected by cig or ros treatment as reported in the above sections.

\section{PPAR $\gamma$ ligands reduce the secretion of GH from GH3 cells}

$\mathrm{GH} 3$ cells were treated with $1-50 \mu \mathrm{M}$ ros for up $72 \mathrm{~h}$, and culture media and cellular extracts were collected 


\section{GH3 cells}

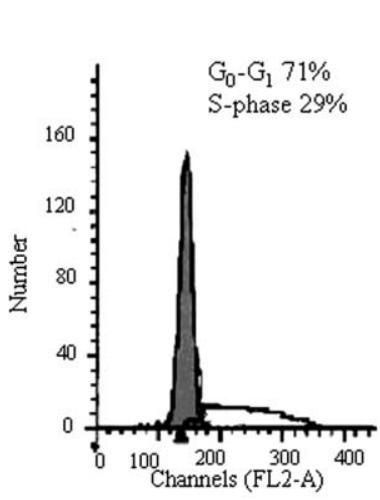

Vehicle

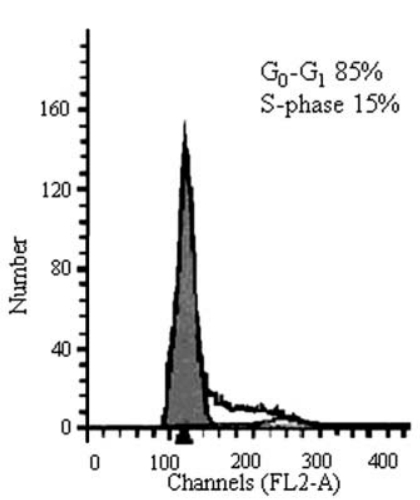

Cig-treated cells

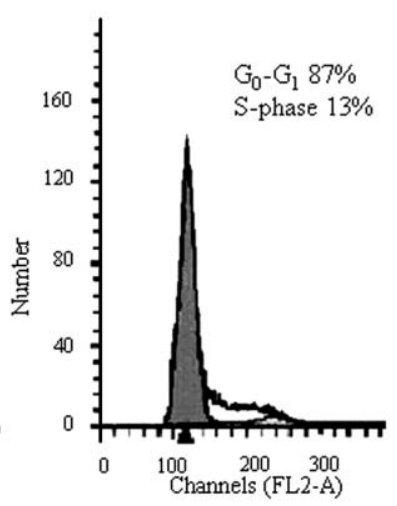

Ros-treated cells

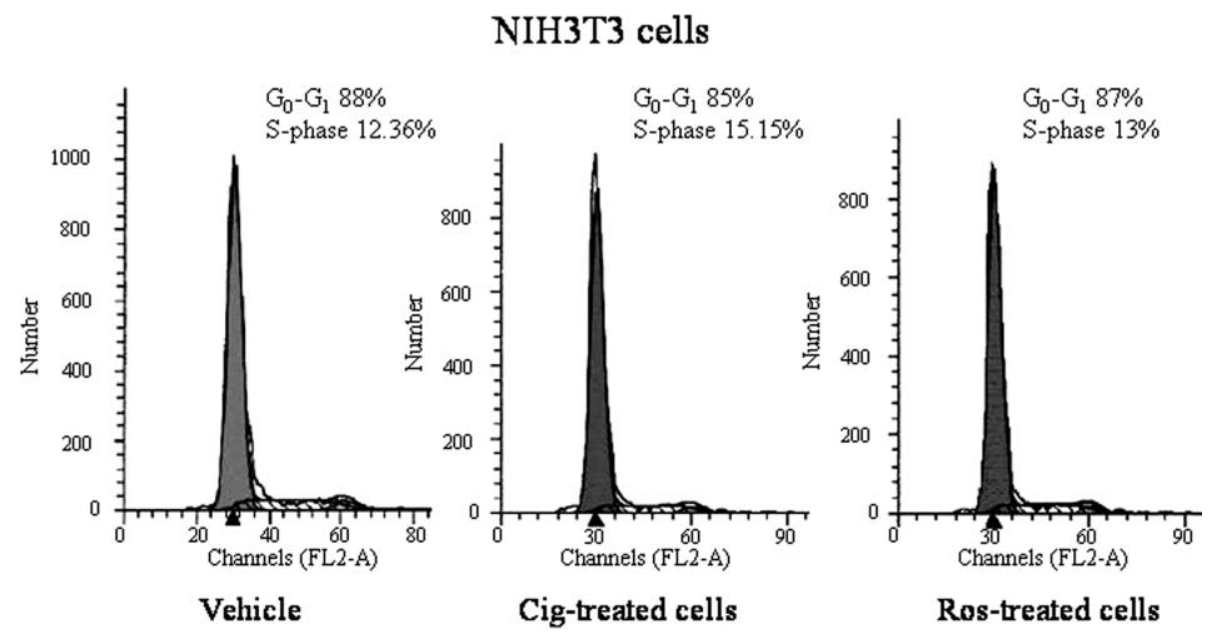

Figure 3 Inhibition of GH3 proliferation by PPAR $\gamma$ ligands. FACS analysis of normally grown GH3 cells treated with $10-50 \mu \mathrm{M}$ cig or ros revealed an increased number of cells in G0-G1 phase (92 $\pm 4 \%$ vs $73 \pm 3 \%$ in controls, $P<0.001$ ) and a reduced number of cells in S-phase $(8.5 \pm 0.9 \%$ vs $18.5 \pm 0.5 \%$ in controls, $P<0.0001)$, indicating a decreasing proliferation activity of the PPAR ligand-treated cells (panel 1). Similar results were obtained using starved cells. Treatment of NIH3T3 cells with either $50 \mu \mathrm{M}$ ros or cig did not affect cell cycle (panel 2).

for $\mathrm{GH}$ determinations. An amount of $10 \mu \mathrm{M}$ ros reduced GH concentrations in culture media from $8.3 \pm 1.4$ to $1.9 \pm 0.7 \mathrm{ng} / \mathrm{ml}$ after $24 \mathrm{~h}(P<0.04)$, from $16.5 \pm 3.7$ to $3.6 \pm 0.9 \mathrm{ng} / \mathrm{ml}$ after $48 \mathrm{~h}$ $(P<0.03)$ and from $43.7 \pm 5.4$ to $2.1 \pm 0.3 \mathrm{ng} / \mathrm{ml}$ after $72 \mathrm{~h}(P<0.0001)$ (Fig. 5, panel 1$)$. Ros at $1-$ $50 \mu \mathrm{M}$ reduced $\mathrm{GH}$ concentrations in culture media in a dose-dependent manner $(P<0.04)$ (Fig. 5, panel $2)$. GH concentrations decreased in cell extracts from ros-treated cells from $233 \pm 13$ to $109 \pm 11 \mathrm{ng} / \mathrm{ml}$ $(P<0.004)$ (Fig. 5, panel 2).

\section{PPAR $\gamma$ ligands reduce transcriptional activity of human GH promoter}

The levels of expression of GH mRNA were measured in either untreated or $1-10 \mu \mathrm{M}$ cig- or ros-treated GH3 cells by RT-PCR. GH transcripts reduced from $5.7 \times 10^{6}$ in untreated cells to $3.0 \times 10^{6}$ and $1.8 \times 10^{6}$ copies in 1 and $10 \mu \mathrm{M}$ cig-treated cells respectively $(P<0.002)$. Cells treated with $1-10 \mu \mathrm{M}$ ros had a similar response (Fig. 6, panel 1). RNA obtained from NIH3T3 cells was used as a negative control. Since cig and ros had very similar effects on the transcription of hGH gene, in the next experiments we used only one TDZ.

The $-397 /+1,-397 /-144$, and $-144 /+1$ DNA fragment of the $5^{\prime}$-flanking region of the $\mathrm{GH}$ gene were used as ${ }^{32} \mathrm{P}$-labeled probes in gel mobility shift assays; $\operatorname{PPAR} \gamma-\mathrm{RXR} \alpha$ heterodimers bound to the $-397 /+1$ and the $-397 /-144$ DNA fragment (data not shown); the latter and shorter probe was then used for further experiments. The PPAR $\gamma-\mathrm{RXR} \alpha$ heterodimer formed a specific complex with the $\mathrm{GH}$ promoter, indicating 

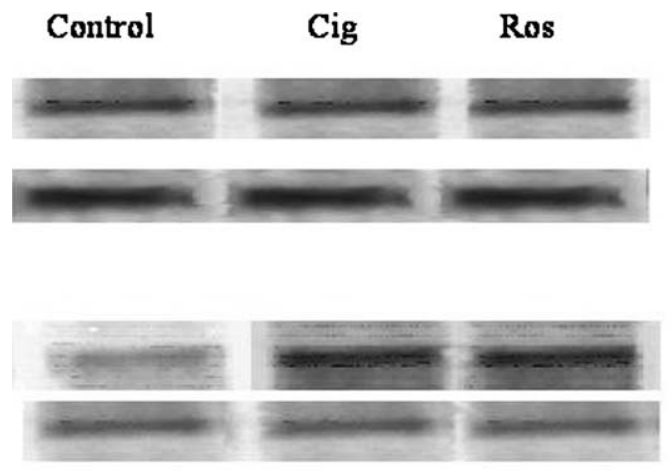

TRAIL

B Actin

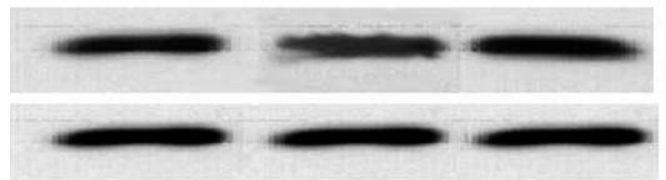

BAX

$\beta$ Actin

Figure 4 Activation of PPAR $y$ is associated with changes in the expression of apoptotic factors. GH3 cell extracts were prepared as described in Materials and methods. Cells were treated with $50 \mu \mathrm{M}$ of either cig or ros for up $72 \mathrm{~h}$. Western blotting was done with anti-p53-, anti-TRAIL- and anti-Bax-specific antibody. Activation of PPAR $\gamma$ by cig or ros was associated with increased expression of TRAIL proteins, leaving unaffected p53 and BAX expression.

the presence of a putative PPRE in the hGH gene (Fig. 6, panel 2). Addition of $10 \mu \mathrm{M}$ cig reduced the binding of the PPAR $\gamma-\mathrm{RXR} \alpha$ heterodimer to the hGH promoter (Fig. 6, panel 2). The pBLCAT3-hGH $-397 /+1$ plasmid was transfected into GH3 cells alone or with pSG5PPAR $\gamma$ and/or pSG $5-\mathrm{RXR} \alpha$. Treatment of the transfected cells with cig decreased the CAT activity by $50 \%$ $(P<0.0005$ vs untreated cells). Cotransfection with PPAR $\gamma$ and $R X R \alpha$ further reduced the CAT activity by up to $65 \%(P<0.0001$ vs untreated cells; $P=$ NS vs cig-treated cells not transfected with PPAR $\gamma$ and $\operatorname{RXR} \alpha$ ) (Fig. 6, panel 3).

\section{Ros treatment slows progression of pituitary GH-secreting tumors and reduces GH secretion in rats}

Five-week-old female Wistar-Furth rats were injected subcutaneously with $2 \times 10^{6} \mathrm{GH} 3$ cells. After 3 weeks, all animals developed $2 \mathrm{~cm}$ subcutaneous tumors. Rats were randomly assigned to receive either ros $(120 \mathrm{mg} / \mathrm{kg}$ per day) $(n=5)$ or vehicle $(n=5)$. The dose of ros was based on that reported to be effective in other studies $(29,30)$ and on experiments with lower doses of ros ( $40 \mathrm{mg} / \mathrm{kg}$ per day), which were ineffective (Fig. 7). After 3-4 weeks, tumor size increased in vehicle-treated rats; in contrast, ros-treated animals had a slower increase of tumor weight $(14.8 \pm 4.2 \mathrm{~g}$ vs $24.1 \pm 2.0 \mathrm{~g}$ in placebo-treated rats, $P<0.03$ ) (Fig. 7, panels 1-2). According to the smaller weight of TZDs-treated rats, serum GH concentrations were lower in rats treated with $120 \mathrm{mg} / \mathrm{kg}$ per day TZDs $(871 \pm 67 \mathrm{ng} / \mathrm{ml})$ than in placebo-treated rats $(1.309 \pm 238)$ or rats treated with $40 \mathrm{mg} / \mathrm{kg}$ per day TZDs $(1.289 \pm 327)$ dose $(* P<0.05)$ (Fig. 7, panel 3).

\section{Discussion}

PPAR $\gamma$ is considered a tumor-suppressor gene, the activation of which leads to cellular differentiation, apoptosis and arrest of tumor progression (23-28, 36). Recently, we showed a possible link between GH-IGF-I hypersecretion and PPAR $\gamma$ in the colonic mucosa of acromegalic patients $(31,34)$. The involvement of $\operatorname{PPAR} \gamma$ in pituitary diseases has been indicated by recent reports by Heaney et al. $(29,30)$ : its expression
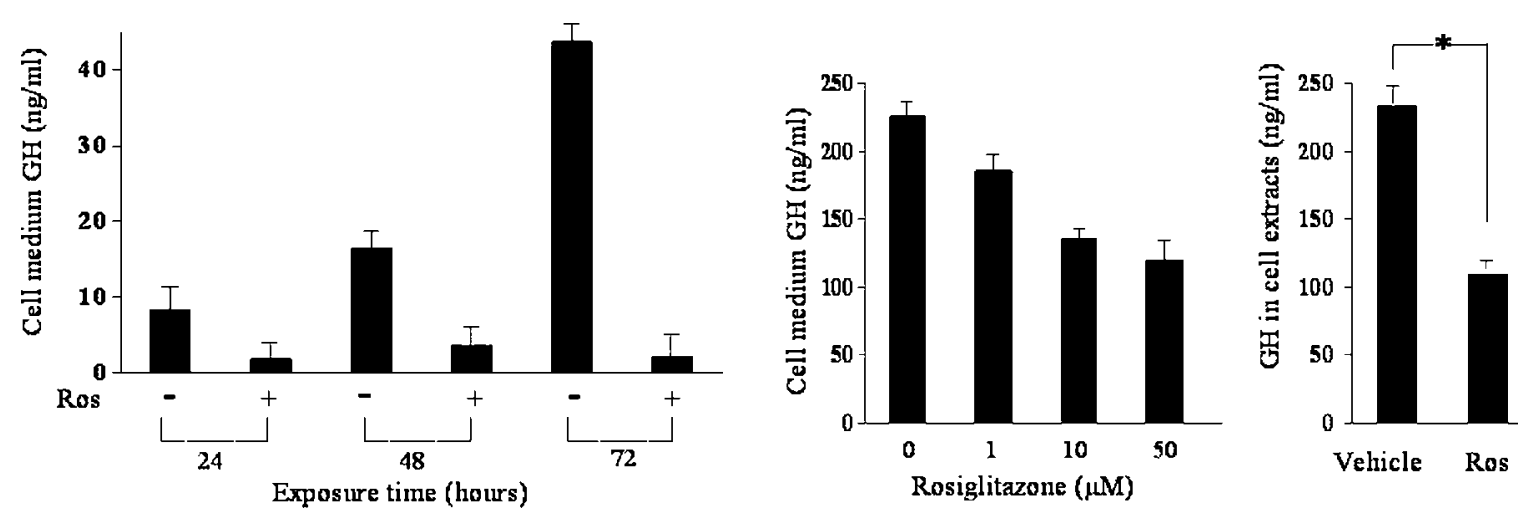

Figure 5 PPAR $\gamma$ ligands reduce the secretion of $\mathrm{GH}$ from GH3 cells. GH3 cells were cultured as described in the Materials and methods and exposed to $1-50 \mu \mathrm{M}$ ros for up to $72 \mathrm{~h}$. Cellular extracts were obtained from ros-treated or untreated cells, as described in Materials and methods. Measurements of rat GH was performed in culture media and in cellular extracts by radioimmunologic assay. In the latter, values were normalized by the protein concentrations. PPAR $\gamma$ ligands significantly reduced the concentrations of GH in culture media from $8.3 \pm 1.4$ to $1.9 \pm 0.7 \mathrm{ng} / \mathrm{ml}$ after $24 \mathrm{~h}(P<0.04)$, from $16.5 \pm 3.7$ to $3.6 \pm 0.9 \mathrm{ng} / \mathrm{ml}$ after $48 \mathrm{~h}(P<0.03)$ and from $43.7 \pm 5.4$ to $2.1 \pm 0.3 \mathrm{ng} / \mathrm{ml}$ after $72 \mathrm{~h}(P<0.0001)$ (panel 1). Ros at $1-50 \mu \mathrm{M}$ reduced GH concentrations in culture media in a dose-dependent manner $(P<0.04)$ (panel 2). GH concentrations decreased in cell extracts from ros-treated cells from $233 \pm 13$ to $109 \pm 11 \mathrm{ng} / \mathrm{ml}\left({ }^{*} P<0.004\right)$ (panel 2); these findings indicate that ros reduces $\mathrm{GH}$ secretion and may also affect GH synthesis. 

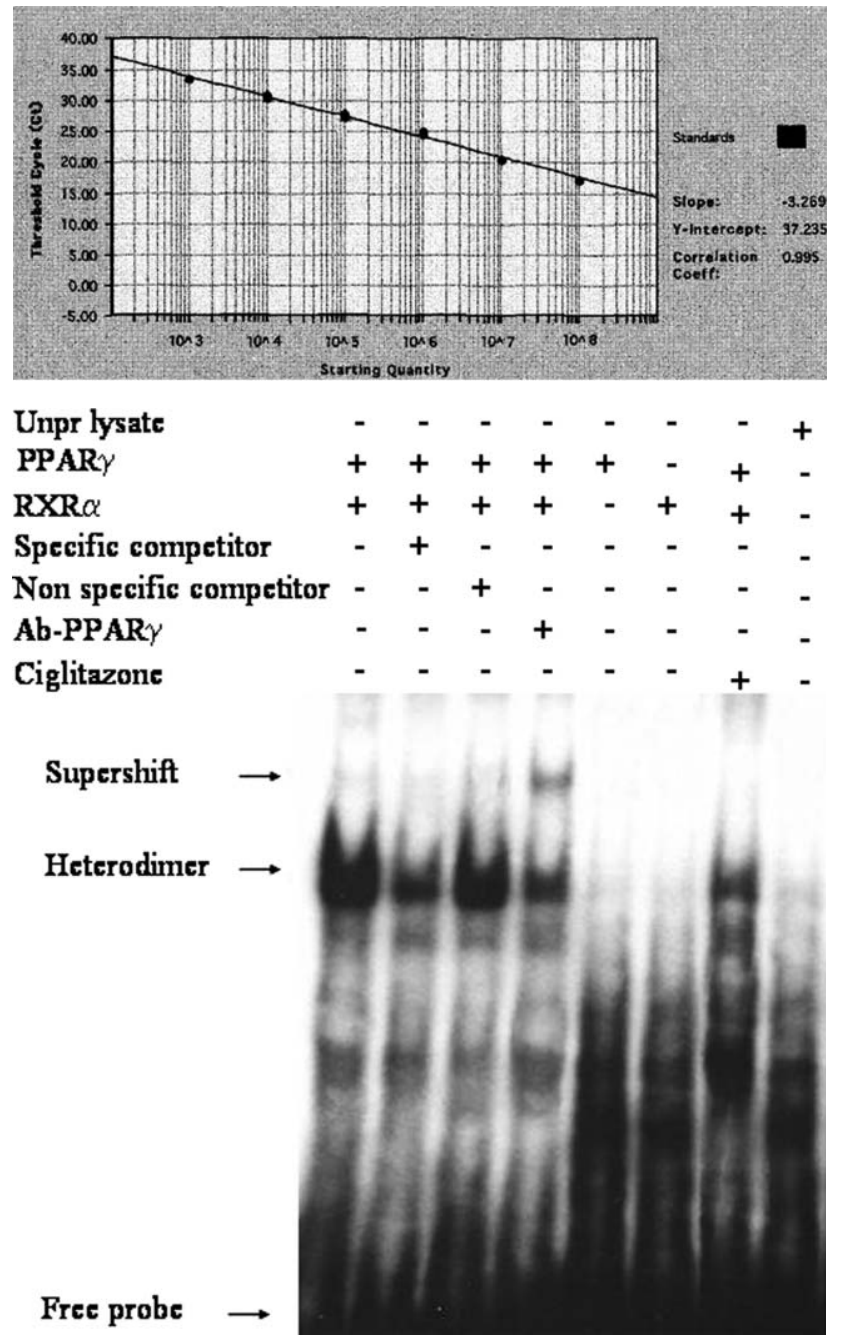
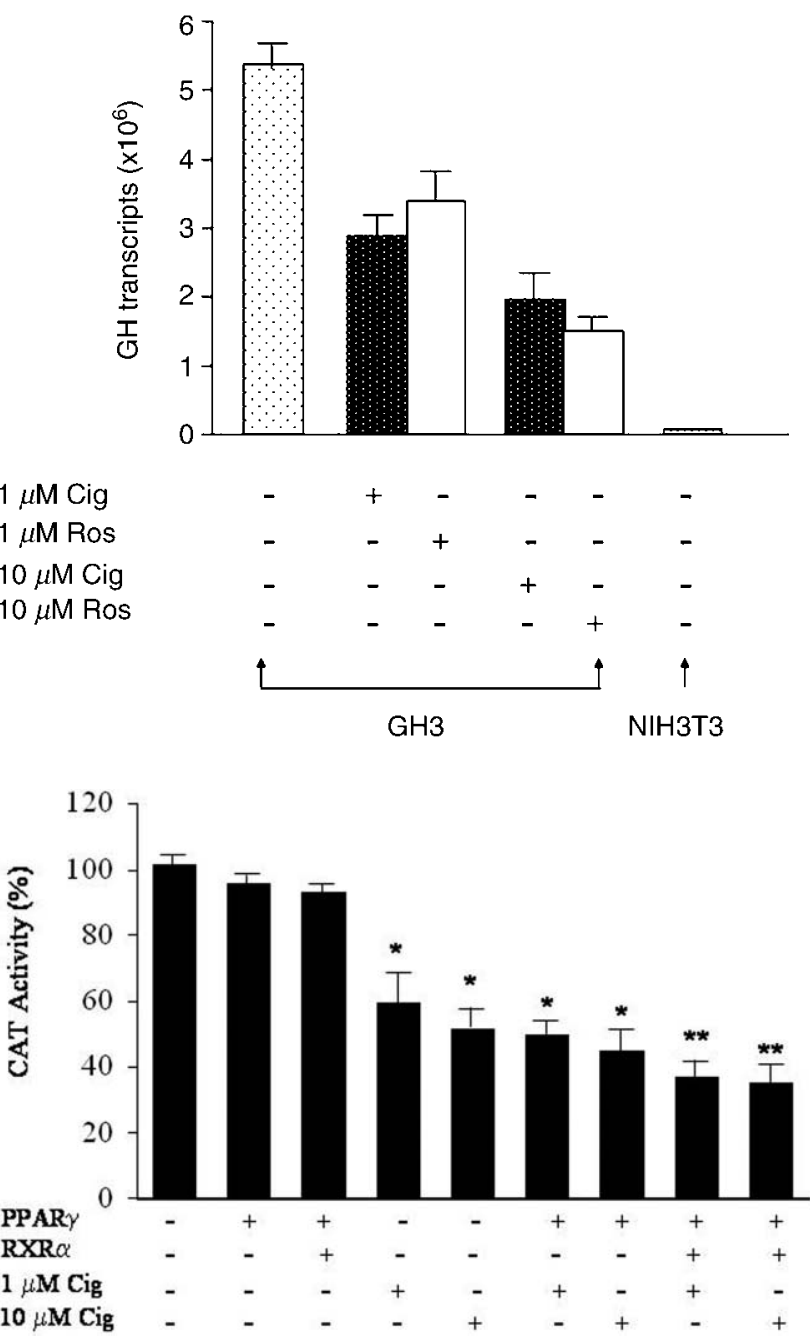

Figure 6 PPAR $y$ ligands reduce the transcriptional activity of the hGH promoter. Panels 1 and 2) Expression of GH mRNA in GH3 cells treated with either $1-10 \mu \mathrm{M}$ cig (filled columns) or ros (empty columns); analysis of GH expression was made by RT-PCR. The representative standard curve for quantitative RT-PCR for GH is shown in panel 1; the threshold cycle (Ct; that is, the PCR cycle number at which the fluorescence signal reached above baseline) was -3.269 (starting copy number) $+37.265(r=0.995)$. Panel 2) GH levels in ros-treated GH3 cells decreased from to $5.7 \times 10^{6}$ to $1.8 \times 10^{6}$ transcripts $(P<0.002)$, similarly to those observed in cig-treated cells. Panel 3) Gel mobility shift assay used the -397/-144 DNA sequence of the human GH promoter as a ${ }^{32}$ P-labeled probe: the specific complex of PPAR $\gamma$-RXR $\alpha$ heterodimer with hGH promoter is shown by arrows. Panel 4) The pBLCAT3-hGH plasmid containing the $-397 /+1$ flanking region of the hGH gene was transfected into the GH3 cells. Exposure of the transfected cells to 1-10 $\mu \mathrm{M}$ ros decreased the CAT activity by up to $70 \%$. CAT activity was expressed as a percentage of the value obtained in absence of drug, which was arbitrarily considered $100 \%$.

seems to be restricted to ACTH-secreting cells only in the normal pituitary, while pituitary adenomas have an abundant expression of this nuclear receptor. PPAR $\gamma$ may induce cell-cycle arrest and apoptosis in pituitary hormone-secreting tumors and nonfunctioning adenomas $(29,30)$. Treatment with TZDs given simultaneously with the injection of GH3 cells retarded the development of subcutaneous GH-secreting tumors in nude mice (30). We believe that, albeit important, this observation has some limitations. The expression of PPAR $\gamma$ was studied in only three pituitary pure GH-secreting adenomas, while our series included 14 consecutive acromegalic patients showing a variable expression of this nuclear receptor; in conflict with the report of Heaney et al. $(29,30)$, normal pituitary tissue showed a high expression of PPAR $\gamma$ which colocalized with GH. One explanation might be the different origin of normal pituitary tissue: autoptic in the study of Heaney et al. but fresh tissue in the present paper. The variation in the expression of PPAR $\gamma$ in GH-secreting adenomas was not related to serum GH or IGF-1 levels nor to the weight of adenomas (data not shown); however, it could not be ruled out that the long-standing exposure to high GH-IGF1 concentrations may play a role in reducing the expression of PPAR $y$ in the pituitary adenomas, as reported for the 


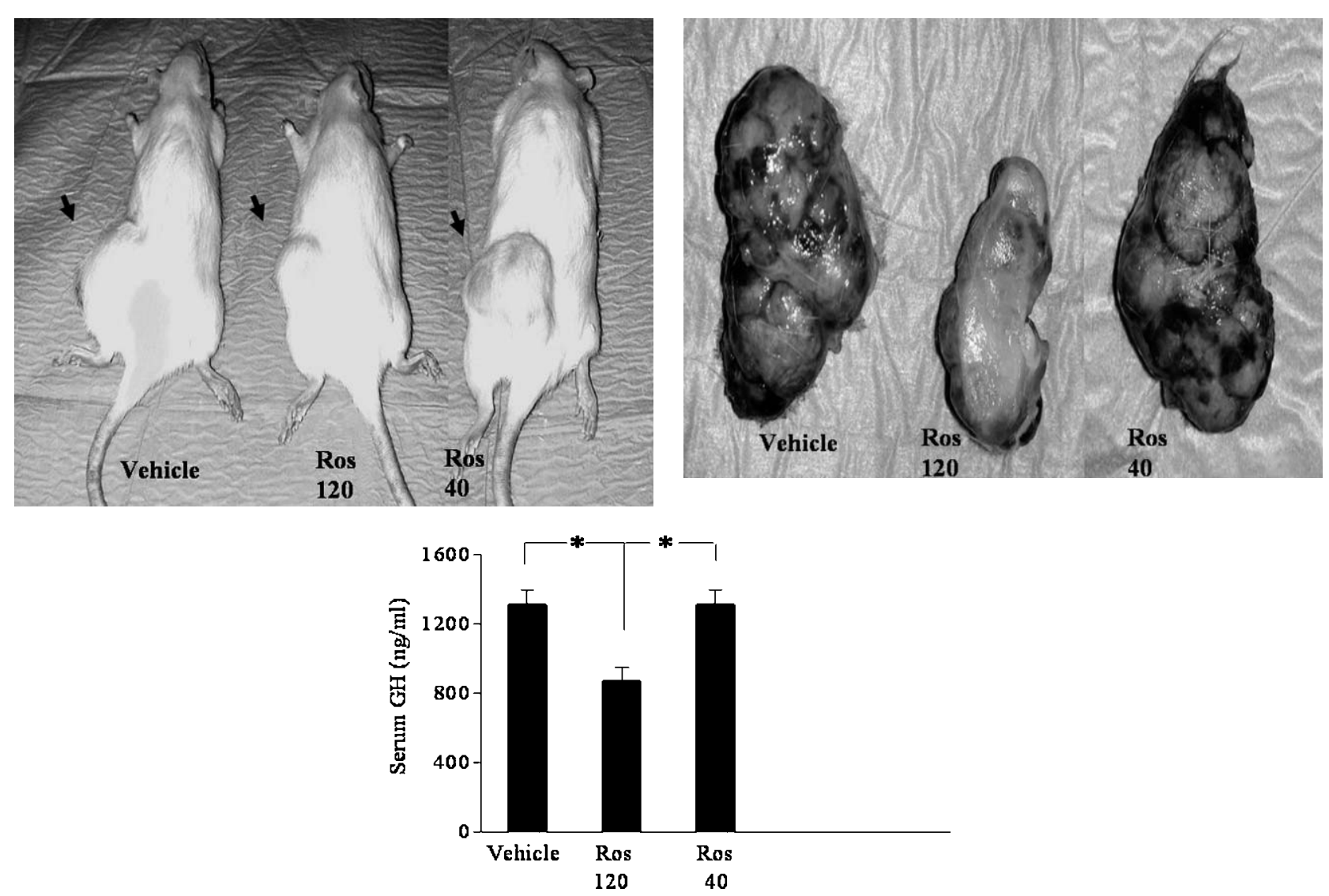

Figure 7 Ros treatment reduces pituitary GH-secreting tumor growth and GH secretion in rats. Wistar-Furth rats were inoculated subcutaneously with $2 \times 10^{6} \mathrm{GH} 3$ cells and randomized to receive ros $(120 \mathrm{mg} / \mathrm{kg}$ per day) $(n=5)$ or placebo $(n=5)$ after tumor development. The daily dose was based on a preliminary study using $40 \mathrm{mg} / \mathrm{kg}$ per day ros, which was ineffective (panel 1). Tumor size at baseline was similar in the two groups of rats; tumor size increased in placebo-treated rats but had a slower progression in ros-treated animals. The animals were killed and tumors weighed; mean tumor weight was $24 \pm 2 \mathrm{~g}$ in placebo-treated rats and $14.8 \pm 4.2 \mathrm{~g}$ in ros-treated animals $(P<0.03)$ (panels 1 and 2$)$. Blood samples were obtained before starting treatment with 40 or $120 \mathrm{mg} / \mathrm{kg}$ per day ros or placebo, and when animals were killed, serum GH concentrations were measured by radioimmunoassay, as described in Materials and methods. Serum GH concentrations were lower in rats treated with $120 \mathrm{mg} / \mathrm{kg}$ per day TZDs (871 $\pm 67 \mathrm{ng} / \mathrm{ml})$ than in placebo-treated rats $(1.309 \pm 238)$ or rats treated with $40 \mathrm{mg} / \mathrm{kg}$ per day TZDs $(1.289 \pm 327)$ dose $\left({ }^{\star} P<0.05\right)($ panel 3$)$.

colonic mucosa $(31,34)$ of some acromegalic patients. More important, our data clearly showed that TZDs treatment can slow the growth of well-established $\mathrm{GH}$-secreting tumors. Heaney et al. showed the preventive effects of TZDs on tumor development. In fact, nude mice injected with GH3 cells and simultaneously treated with TZDs had delayed development of subcutaneous tumors, which grew more slowly than those of controls. We started the treatment with TZDs only after complete development of subcutaneous tumors, the growth of which was only partially reduced. This is the situation occurring in vivo in humans, because the treatment is initiated only after tumors have developed and grown. GH concentrations, measured either in the culture media of $\mathrm{GH} 3$ cells treated with ros or in the blood from rats treated with this drug, clearly decreased. The fact that we did not observe a significant tumor shrinkage after ros treatment might also be due to the greater volume of the tumors with respect to those reported by Heaney et al. $(29,30)$.

Our data clearly demonstrated that TZDs also affected the synthesis of $\mathrm{GH}$; in fact, $\mathrm{GH} 3$ cells treated with TZDs had a more reduced intracellular content of $\mathrm{GH}$ than controls. Moreover, $\operatorname{PPAR} \gamma-\mathrm{RXR} \alpha$ heterodimers bind to and inhibit the transcriptional activity of the human $\mathrm{GH}$ promoter; this resulted in a reduction in GH mRNA levels in GH3 cells treated with cig or ros. Thus, PPAR $\gamma$ ligands might effectively reduce $\mathrm{GH}$ hypersecretion, either reducing GH transcription and secretion or increasing the apoptosis and arresting the growth of pituitary GH-secreting cells. Whether the maximum dose of ros allowed in humans will cause GH deficiency remains to be elucidated; however, this outcome seems to be unlikely either because this dose might not be sufficient in reducing GH secretion or because of the compensatory mechanisms of the complex signaling network regulating GH secretion. 
Our data also showed that increased TRAIL protein expression might be a common effector of PPAR $\gamma-$ induced apoptosis in $\mathrm{GH} 3$ cells, as reported for other transcription factors (37). Unlike other pituitary cell lines, in which TZDs treatment was associated with downregulation of $\mathrm{Bcl}-2$ and increased expression of Bax (30), GH3 cells did not exhibit variations of these apoptotic proteins under TZDs exposure. These effects of PPAR $\gamma$ ligands were specific since they were not observed in NIH3T3 cells, which did not express detectable amount of PPAR $\gamma$.

Ros is currently employed in the treatment of type 2 diabetes as a monotherapy or in combined therapy. Its metabolism in the liver differs from that of troglitazone, and this might explain its low incidence of hepatic abnormalities (38). However, the dose effective in lowering $\mathrm{GH}$ secretion and to induce apoptosis in GH3-induced tumors was higher than those used in the treatment of type 2 diabetes. Therefore, a note of caution is necessary. It also should be pointed out that similar doses of TZDs have been used in preventing atherosclerosis or to treat thyroid tumors in mice $(24,38,39)$. TZDs have also been used for treating human liposarcoma or prostate cancer at doses higher than those employed for glycemic control $(23,40)$. In conclusion, although our results need to be validated in clinical trials, they provide the molecular basis for the use of TZDs as adjunct therapeutic agents in the challenging management of acromegalic patients.

\section{Acknowledgements}

We thank Professor Aldo Pinchera for his constant encouragement and advice. This work was partially supported by grants from the University of Pisa (Fondi d'Ateneo) and Ministero dell'Istruzione, dell'Università e della Ricerca (M.I.U.R.) Rome, to E.M., from the University of Insubria at Varese to L.B., and from M.I.U.R., Rome, to L.B.

\section{References}

1 Giustina A, Barkan A, Casanueva FF, Cavagnini F, Frohman L, Ho K et al. Criteria for cure of acromegaly: a consensus statement. Journal of Clinical Endocrinology and Metabolism $2000 \mathbf{8 5}$ 526-529.

2 Jones JI \& Clemmons DR. Insulin-like growth factors, and their binding proteins: biological actions. Endocrinology Reviews 1995 $163-26$.

3 Frohman LA. Acromegaly: what constitutes optimal therapy? Journal of Clinical Endocrinology and Metabolism $1996 \mathbf{8 1}$ $443-445$.

4 Kreutzer J, Vance ML, Lopes MB \& Laws ER Jr. Surgical management of GH-secreting pituitary adenomas: an outcome study using modern remission criteria. Journal of Clinical Endocrinology and Metabolism $2001864072-4077$.

5 Ross DA \& Wilson CB. Results of trans-sphenoidal microsurgery for growth hormone-secreting pituitary adenoma in a series of 214 patients. Journal of Neurosurgery $1988 \mathbf{6 8} 854-867$.

6 Brada M, Rajan B, Traish D, Ashley S, Holmes-Sellors PJ, Nussey S et al. The long-term efficacy of conservative surgery and radiotherapy in the control of pituitary adenomas. Clinical Endocrinology $1993 \mathbf{3 8} 571-578$.

7 Fahlbusch R, Honegger J \& Buchfelder M. Surgical management of acromegaly. Endocrinology and Metabolism Clinics of North America $199221669-692$.

8 Wright AD, Hill DM, Lowy C \& Fraser TR. Mortality in acromegaly. Quarterly Journal of Medicine 197039 1-16.

9 Orme SM, McNelly RJ, Cartwright RA \& Belchetz PE. Mortality and cancer incidence in acromegaly: a retrospective cohort study. United Kingdom Acromegaly Study Group. Journal of Clinical Endocrinology and Metabolism 199883 2730-2734.

10 Barrande G, Pittino-Lungo M, Coste J, Ponvert D, Bertagna X, Luton JP et al. Hormonal and metabolic effects of radiotherapy in acromegaly: long-term results in 128 patients followed in a single center. Journal of Clinical Endocrinology and Metabolism $2000853779-3785$.

11 Barkan AL, Halasz I, Dornifield KJ, Jaffe CA, Friberg RD, Chandler WF et al. Pituitary irradiation is ineffective in normalizing plasma insulin-like growth factor I in patients with acromegaly. Journal of Clinical Endocrinology and Metabolism $1997 \mathbf{8 2}$ 3187-3191.

12 Ezzat S, Snyder PJ, Young WF, Boyajy LD, Newman C, Klibanski A et al. Octreotide treatment of acromegaly. A randomized, multicenter study. Annals of Internal Medicine 1992117 711-718.

13 Newman CB, Melmed S, Snyder PJ, Young WF, Boyajy LD, Levy R et al. Safety and efficacy of long-term octreotide therapy of acromegaly: results of a multicenter trial in 103 patients-a clinical research center study. Journal of Clinical Endocrinology and Metabolism $1995 \mathbf{8 0} 2768-2775$.

14 Lamberts SWJ, Van der Lely A-J, De Herder WW \& Hofland LJ. Octreotide. New England Journal of Medicine 1996334 246-253.

15 Colao A, Ferone D, Lastoria S, Marzullo P, Cerbone G, Di Sarno A et al. Prediction of efficacy of octreotide therapy in patients with acromegaly. Journal of Clinical Endocrinology and Metabolism $1996812356-2362$.

16 Desvergne B \& Wahli W. Peroxisome proliferator activated receptors: nuclear control of metabolism. Endocrinology Review 1999 20 649-688.

17 Auboeuf D, Rieusset J, Fajas L, Vallier P, Frering V, Riou JP et al. Tissue distribution and quantification of the expression of mRNAs of peroxisome proliferator activated receptors and liver $\mathrm{X}$ receptor alpha in humans: no alteration in adipose tissue of obese and NIDDM patients. Diabetes 199746 1319-1327.

18 Lowell BB. PPAR $\gamma$ : an essential regulator of adipogenesis and modulator of fat cell function. Cell 199999 239-242.

19 Sarraf P, Mueller E, Smith WM, Wright HM, Kum JB, Aaltonen LA et al. Loss-of-function mutations in PPAR gamma associated with human colon cancer. Molecular Cell 19993 799-804.

20 Huin C, Corriveau L, Keller JM, Collet P, Kremarik-Bouillaud P, Domenjoud L et al. Differential expression of peroxisome proliferator-activated receptors (PPARs) in the developing human fetal digestive tract. Journal of Histochemistry and Cytochemistry 2000 48 1-9.

21 Gupta RA \& DuBois RN. Controversy. PPARgamma as a target for treatment of colorectal cancer. American Journal of Physiology $2002 \mathbf{2 8 3}$ G266-G268.

22 Sporn MB, Suh N \& Mangelsdorf DJ. Prospects for prevention and treatment of cancer with selective PPARgamma modulators (SPARMs). Trends in Molecular Medicine 20017 395-400.

23 Demetri GD, Fletcher CDM, Mueller E, Sarraf P, Naujoks R, Campbell $\mathrm{N}$ et al. Induction of solid tumor differentiation by the peroxisome proliferator-activated receptor- $\gamma$ ligand troglitazone in patients with liposarcoma. PNAS $1999963951-3956$.

24 Kubota T, Koshizuka K, Williamson EA, Asou H, Said JW, Holden $\mathrm{S}$ et al. Ligand for peroxisome proliferator-activated receptor $\gamma$ (troglitazone) has potent antitumor effect against human prostate cancer both in vitro and in vivo. Cancer Research $1998 \mathbf{5 8}$ $3344-3352$.

25 Elstner E, Muller C, Koshizuka K, Williamson EA, Park D, Asou H et al. Ligands for peroxisome proliferator activated receptor $\gamma$ and 
retinoic acid receptor inhibit growth and induce apoptosis of human breast cancer cells in vitro and BNX mice. PNAS 1998 $958806-8811$.

26 Zander T, Kraus JA, Grommes C, Schlegel U, Feinstein D, Klockgether $\mathrm{T}$ et al. Introduction of apoptosis in human and rat glioma by antagonist of the nuclear receptor PPARgamma. Journal of Neurochemistry $2002 \mathbf{8 1} 1052-1060$.

27 Otha K, Endo T, Haraguchi K, Hershaman JM \& Onaya T. Ligands for peroxisome proliferators-activated receptor gamma inhibit growth and induce apoptosis of human papillary thyroid carcinoma cells. Journal of Clinical Endocrinology and Metabolism $2001862170-2177$.

28 Shimada T, Kojima K, Yoshiura K, Hirashi H \& Terano A. Characteristics of the peroxisome proliferator activated receptor $\gamma$ $(\operatorname{PPAR} \gamma)$ ligand induced apoptosis in colon cancer cells. Gut $20025 \mathbf{5 0} 658-664$.

29 Heaney AP, Fernando M, Yong WH \& Melmed S. Functional PPAR-gamma receptor is a novel therapeutic target for ACTHsecreting pituitary adenomas. Nature Medicine $2002 \mathbf{8}$ 1281-1287.

30 Heaney AP, Fernando M \& Melmed S. PPAR-gamma receptor ligands: novel therapy for pituitary adenomas. Journal of Clinical Investigation 2003111 1381-1388.

31 Bogazzi F, Ultimieri F, Raggi F, Russo D, Viacava P, Cecchetti P et al. Changes in the expression of the peroxisone proliferator activated receptor $\gamma$ gene in the colonic polyps and colonic mucosa of acromegalic patients. Journal of Clinical Endocrinology and Metabolism 200388 3938-3942.

32 Roy RJ, Gossellin P \& Guèrin SL. A short protocol for micro-purification of nuclear proteins from whole animal tissue. Biotechniques $199111770-777$.

33 Bogazzi F, Hudson LD \& Nikodem VM. A novel heterodimerization partner for thyroid hormone receptor. Peroxisome proliferator activated receptor. Journal of Biological Chemistry 1994269 11683-11686.

34 Bogazzi F, Ultimieri F, Raggi F, Costa A, Gasperi M, Cecconi E et al. Peroxisome proliferator activated receptor gamma expression is reduced in the colonic mucosa of acromegalic patients. Journal of Clinical Endocrinology and Metabolism 200287 2403-2406.

35 Westergaard M, Henningen J, Svendsen ML, Johansen C, Jensen UB, Schroder HD et al. Modulation of keratinocyte gene expression and differentiation by PPAR-selective ligands and tetradecylthioacetic acid. Journal of Investigative Dermatology 2001 $116702-712$.

36 Sarraf P, Mueller E, Jones D, King FJ, DeAngelo DJ, Partridge JB et al. Differentiation and reversal of malignant changes in colon cancer through PPAR $\gamma$. Nature Medicine 1998 4 1046-1052.

37 Goke R, Goke A, Goke B \& Chen Y. Regulation of TRAIL-induced apoptosis by transcription factors. Cellular Immunology 2000201 $77-81$.

38 Barman Balfour JA \& Plosker GL. Rosiglitazone. Drugs 199957 921-930.

39 Li AC, Brown KK, Silvestre MJ, Willson TM, Palinski W \& Glass CK. Peroxisome proliferator-activated receptor gamma ligands inhibit development of atherosclerosis in LDL receptor-deficient mice. Journal of Clinical Investigation 2000106 523-531.

40 Mueller E, Smith M, Sarraf P, Kroll T, Aiyer A, Kaufman DS et al. Effects of ligand activation of peroxisome proliferator-receptor $\gamma$ in human prostate cancer. PNAS 200097 10990-10995.

Received 11 December 2003

Accepted 11 February 2004 